\title{
Effect of bypass methionine-lysine supplementation on haematological and blood biochemical parameters of J affarabadi heifers
}

\author{
J. K. Movaliya, K. S. Dutta, R. J. Padodara, A. R. Bhadaniya and H. H. Savsani \\ Veterinary College, \\ J unagadh Agricultural University, Junagadh, Gujarat, India. \\ Corresponding author: R. J. Padodara, email: rameshpadodara3@gmail.com \\ Received: 06-07-2012, Accepted: 04-08-2012, Published online: 27-12-2012
}

\begin{abstract}
How to cite this article: Movaliya JK, Dutta KS, Padodara RJ, Bhadaniya AR and Savsani HH (2013) Effect of bypass methionine-lysine supplementation on haematological and blood biochemical parameters of Jaffarabadi heifers, Vet World 6(3): 147-150, doi: 10.5455/vetworld.2013.147-150
\end{abstract}

\begin{abstract}
Aim: The objective of an experiment was conducted to evaluate the effect of feeding bypass Methonine-Lysine on hematological and biochemical parameters on growing Jaffrabadi heifers of age from 12 to 18 month.

Material and Methods: Eighteen Jaffrabadi heifers were divided into three groups of equal number: control group $\left(\mathrm{T}_{1}\right)$, cotton seed cake (CSC) $\left(\mathrm{T}_{2}\right)$ and bypass Methionine-Lysine supplementation $\left(\mathrm{T}_{3}\right)$. Blood samples were collected on the $1^{\text {st }}$ and $63^{\text {rd }}$ day of the trail. A close examination of the nutritive effects of treatment of CSC and bypass Methionine and Lysine (M-L) supplementation on hematological and biochemical values in the blood (white blood cell count (WBC), red blood cell count (RBC), hemoglobin (Hb), pack cell volume (PCV), mean corpuscular volume (MCV), mean corpuscular hemoglobin (MCH), mean corpuscular hemoglobin concentration (MCHC), platelets count (PLT), total protein, albumin, globulin, blood urea nitrogen (BUN), creatinine and creatine kinase was carried out.

Results: $\mathrm{BUN}$ had a tendency to decrease in $\mathrm{T}_{2}$ and $\mathrm{T}_{3}(\mathrm{P}<0.05)$ by the end of the trail with compare to control but no significant difference was observed between $\mathrm{T}_{2}$ and $\mathrm{T}_{3}$. No significant differences were found between treatments in other hematological and biochemical parameters like total protein, albumin, globulin, creatinine and creatine kinase.
\end{abstract}

Conclusion: Bypass Methionine and Lysine have no effect on hematological and biochemical parameters except blood urea nitrogen (BUN) in growing Jaffrabadi heifers.

Keywords: biochemical values, bypass methionine-lysine, hematological, jaffrabadi heifer.

\section{Introduction}

Ruminant animals require two types of digestible protein. The first is a degradable protein in the rumen which is degraded by the micro-organisms in rumen to produce microbial protein. The second is the bypass protein which escapes microbial digestion in rumen and is digested directly in the small intestine. Rumen degradable protein is used to synthesize microbial protein which is valuable metabolisable protein source for the animal. Metabolisable protein (MP) consists of bypass protein and microbial protein. Excessive degradation of valuable protein in rumen by the microorganisms results in degradation of high quality protein and up gradation of poor quality protein as well as in some losses of Nitrogen as urea in urine. Rumen microbes have the ability to synthesize all the essential amino acids but microbial population in rumen alone cannot supply all amino acids to a fast growing dairy animal in required amount, and the ruminally undegradable protein/ruminally degradable protein system began to get more usage [1]. Ruminally undegraded feed protein from vegetable sources are usually low in content of Methionine or Lysine [2]. Methionine and Lysine were reported as the first and second respectively limiting amino acids for synthesis of tissue protein in growing ruminants [3]. Methionine,
Lysine and Histidine might be the limiting amino acids in growing beef steers [4]. Archibeque et al., [5] identified Methionine as a limiting amino acid for growing cattle. Supplement of rumen-protected Methionine improves the average daily gain of growing cattle [6]. Blood metabolites and hematological indices of beef cows can be affected by feeding rumen protected Methionine during gestation [7].

Due to limited referential data, the effect of bypass Methionine and Lysine, on Jaffrabadi buffaloes, as one of the potentially deficient amino acids in nutrition of growing heifers, has been studied in this experiment.

\section{Materials and Methods}

The study was approved by the committee formed for the research by the university authority. Eighteen Jaffrabadi buffalo heifers of age from 12 to 18 month were taken in experiment at Cattle Breeding Farm, Junagadh Agricultural University, Junagadh. These animals were divided into three group of six each. $\mathrm{T}_{1}$ feed with $2 \mathrm{Kg}$ Groundnut Gottar + Concentrate mixture to meet out DCP requirement, $\mathrm{T}_{2}$ feed with $2 \mathrm{Kg}$ Groundnut Gottar + Concentrate mixture and cotton seed cake (CSC) (50:50) to meet out DCP requirement and $\mathrm{T}_{3}$ feed with in addition to $\mathrm{T}_{1}$ feeding rumen bypass Methionine and Lysine was supplied at @ 5 and $10 \mathrm{~g} /$ 
Table-1. Percent average composition of feed and fodder (on DM basis) fed to experimental heifers

\begin{tabular}{lcccccc}
\hline $\begin{array}{l}\text { Nutrient } \\
\text { (g/kg DM) }\end{array}$ & Concentrate Mixture & Cotton seed cake & Groundnut gottar & Pasture hay & Meti PEARL\# & Lysi PEARL\# \\
\hline DM & & & & & \\
OM & 93.25 & 94.70 & 91.25 & 94.50 & - & - \\
CP & 86.71 & 31.68 & 90.42 & 85.59 & - & - \\
CF & 21.45 & 22.18 & 04.46 & 02.32 & 55.00 & 40.00 \\
EE & 10.71 & 07.48 & 32.17 & 35.40 & - & - \\
NFE & 03.48 & 32.74 & 01.73 & 01.42 & 44.00 & 50.20 \\
NDF & 51.06 & 55.87 & 51.88 & 46.42 & - & - \\
ADF & 37.30 & 44.51 & 43.80 & 56.70 & - & - \\
Ash & 20.52 & 05.92 & 33.76 & 42.53 & - & - \\
Silica & 13.29 & 01.14 & 09.58 & 14.41 & 01.00 & - \\
Ca & 04.20 & 00.21 & 02.97 & 10.40 & - & - \\
P & 01.17 & 0.86 & 02.34 & 00.45 & - & - \\
Methionine & 00.88 & 00.70 & 00.48 & 00.10 & - & - \\
Lysine & - & 01.57 & - & - & 55.00 & - \\
\hline
\end{tabular}

* Indicate reference value, \# Commercial product of Methionine and Lysine, DM- Dry matter, OM- Organic matter, CP- Crude protein, CF- Crude fibre, EE- Ether extract, NFE- Nitrogen free extract, NDF- Neutral detergent fibre, ADF- Acid detergent fibre, Ca- Calcium, P-Phosphorus.

Table-2. Effect of methionine and lysine supplementation on body weight of $\mathrm{J}$ affrabadi heifers $(n=6)$

\begin{tabular}{llllllll}
\hline Parameters & Days of trial & T-1 & T-2 & T-3 & SEM & C.D. at 5 \% & C.V. \% \\
\hline Body weight $(\mathrm{kg})$ & 1 & 208.27 & 208.32 & 208.30 & 11.11 & NS & 13.16 \\
& 63 & 245.65 & 253.20 & 257.45 & 11.21 & NS & 10.92 \\
Total changes between days of trial & $37.38^{\mathrm{a}}$ & $44.88^{\mathrm{b}}$ & $49.15^{\mathrm{c}}$ & 1.93 & $6.17^{*}$ & 11.45 \\
\hline
\end{tabular}

* Treatment differences were considered significant for $\mathrm{P}<0.05$. NS - Non-significant

head/day respectively with mature pasture grass hay ad $l i b$ to each group. DCP values of each constituent of feed were analysed and mention in Table-1. Blood samples were drawn by puncture of jugular vein in sterile vial on initial (day 1) and final stage (day 63) of experiment for blood analysis. Hematological parameters were analyzed by automatic hematology analyzer (BCVet 2800) and blood chemistry was analyzed from plasma for plasma total proteins by Biuret method, creatinine by modified Jaffe's method, creatinine kinase by UV-kinetic method and BUN by NED-DYE method. Body weights of experimental animals were taken at initiation and termination of experiment and their difference were shown in Table-2.

Experimental data was analyzed statistically followed by Complete Randomized Design (CRD) as per Snedecor and Cochran [8]. Treatment differences were considered significant for $P<0.05$.

\section{Result and Discussion}

Table 3 and 4 are showing data of effect of different treatments verses control group of hematology and blood biochemical parameters in Jaffrabadi heifers respectively.

Hematological data: No significant difference was observed in counts of WBC, RBC, PLT, PCV, hemoglobin and other indices of blood parameters, but mean values were observed increase in WBC, RBC, hemoglobin, PCV and PLT between control group and CSC and M-L supplementation ration groups.

Similar non-significant finding was observed for hematological parameters viz WBC, RBC, $\mathrm{Hb}, \mathrm{PCV}$, PLT, MCH and MCV by Liker et al. [9] after feeding rumen-protected Methionine to cattle. Shahidullah et al. [10] observed blood profile studies after treatment of different doses of blood meal rich in Methionine and Lysine there were decrease of TEC, Hb concentration and PCV and increase of erythrocyte sedimentation rate (ESR) content in the birds. It may be due to higher growth rate of birds compare to control group. Donkoh et al. [11] and Odunsi et al. [12] reported that hematological parameters are unchanged in protein treatment in birds.

Blood constituents in broilers were not significantly increased by different levels of Methionine. Hemoglobin, hematocrit and red blood cells were not significantly affected by dietary Methionine. MCV and MCH were increased significantly by increasing Methionine level, while MCHC was not significantly affected [11].

Blood biochemical data: No significant difference was observed in biochemical parameters like Total protein, albumin, globulin, creatinine and creatine kinase except BUN, which is showing lower significant $(P<0.05)$ difference between the treatment.

Liker et al. [9] showed decrease plasma urea concentration with treatment of rumen-protected Methionine at trial of day 94 but no significant differences were found between the groups in total protein, albumin and creatinine. Plasma total protein and globulin were not significantly affected by Lysine. However, albumin was increased with increasing Lysine [13]. Similar significant decreasing trend of BUN was observed in dairy cow after providing palletize Methionine-Lysine supplementation by Ye $e t$ al. [14].

In dairy cows, urea nitrogen in blood, urine, and milk is mainly derived from excessive ammonia absorbed through the rumen wall from degradation of dietary $\mathrm{CP}$ in the rumen and from the deamination of amino acids (AA), which may be from MP and 


\begin{tabular}{|c|c|c|c|c|c|c|c|}
\hline Parameters & Days of trial & T-1 & $\mathrm{T}-2$ & $T-3$ & SEM & C.D. at $5 \%$ & C.V. $\%$ \\
\hline \multirow[t]{2}{*}{ WBC $\left(10^{3} / \mathrm{cmm}\right)$} & 1 & 15.52 & 16.97 & 13.87 & 0.78 & NS & 20.90 \\
\hline & 63 & 14.63 & 16.13 & 15.30 & 0.63 & NS & 18.01 \\
\hline \multirow[t]{2}{*}{$\mathrm{RBC}\left(10^{6} / \mathrm{cmm}\right)$} & 1 & 7.48 & 7.73 & 8.00 & 0.16 & NS & 9.07 \\
\hline & 63 & 7.98 & 8.43 & 8.18 & 0.14 & NS & 7.39 \\
\hline \multirow[t]{2}{*}{$\mathrm{Hb}(\%)$} & 1 & 13.50 & 14.60 & 14.65 & 0.22 & NS & 5.21 \\
\hline & 63 & 14.65 & 16.17 & 15.52 & 0.27 & NS & 6.71 \\
\hline \multirow[t]{2}{*}{ PCV (\%) } & 1 & 35.42 & 39.33 & 38.70 & 0.73 & NS & 7.18 \\
\hline & 63 & 39.30 & 42.73 & 39.45 & 0.88 & NS & 8.77 \\
\hline \multirow[t]{2}{*}{$\operatorname{MCV}(f L)$} & 1 & 47.53 & 50.91 & 48.49 & 0.68 & NS & 5.36 \\
\hline & 63 & 49.40 & 50.95 & 49.43 & 0.69 & NS & 6.03 \\
\hline \multirow{2}{*}{$\mathrm{MCH}(\mu \mu \mathrm{g})$} & 1 & 18.10 & 18.96 & 18.54 & 0.27 & NS & 6.13 \\
\hline & 63 & 18.35 & 19.17 & 18.53 & 0.24 & NS & 5.34 \\
\hline \multirow[t]{2}{*}{$\mathrm{MCHC}(\%)$} & 1 & 38.15 & 37.30 & 38.27 & 0.25 & NS & 2.70 \\
\hline & 63 & 37.28 & 37.73 & 37.62 & 0.15 & NS & 1.65 \\
\hline \multirow[t]{2}{*}{$\operatorname{PLT}\left(10^{3} / \mathrm{cmm}\right)$} & 1 & 200.67 & 239.67 & 235.67 & 11.96 & NS & 22.42 \\
\hline & 63 & 228.00 & 285.00 & 233.83 & 14.69 & NS & 24.16 \\
\hline
\end{tabular}

NS - Non-significant, SEM- Standard error mean, CD- Critical difference, CV- Coefficient of variance

Table-4. Effect of methionine and lysine supplementation on blood biochemistry of $\mathrm{J}$ affrabadi heifers $(n=6)$

\begin{tabular}{|c|c|c|c|c|c|c|c|}
\hline Parameters & Days of trial & T-1 & T-2 & T-3 & SEM & C.D. at $5 \%$ & C.V. \% \\
\hline \multirow[t]{2}{*}{ Total Protein $(\mathrm{g} / \mathrm{dl})$} & 1 & 6.58 & 6.58 & 6.68 & 0.05 & NS & 3.23 \\
\hline & 63 & 6.40 & 6.50 & 6.77 & 0.09 & NS & 5.50 \\
\hline \multirow{2}{*}{ Albumin (g/dl) } & 1 & 3.32 & 3.49 & 3.46 & 0.04 & NS & 5.12 \\
\hline & 63 & 3.20 & 3.31 & 3.39 & 0.04 & NS & 4.30 \\
\hline \multirow[t]{2}{*}{ Globulin (g/dl) } & 1 & 3.26 & 3.10 & 3.22 & 0.04 & NS & 5.70 \\
\hline & 63 & 3.20 & 3.19 & 3.38 & 0.08 & NS & 11.28 \\
\hline \multirow[t]{2}{*}{$\mathrm{BUN}(\mathrm{mg} / \mathrm{dl})$} & 1 & 22.50 & 22.23 & 21.20 & 0.38 & NS & 7.30 \\
\hline & 63 & $22.93^{\mathrm{a}}$ & $21.00^{\mathrm{b}}$ & $20.48^{\mathrm{b}}$ & 0.42 & $1.85^{\star}$ & 6.99 \\
\hline \multirow{2}{*}{ Creatinine $(\mathrm{mg} / \mathrm{dl})$} & 1 & 1.47 & 1.44 & 1.68 & 0.05 & NS & 10.99 \\
\hline & 63 & 1.48 & 1.42 & 1.54 & 0.04 & NS & 10.38 \\
\hline \multirow[t]{2}{*}{ Creatine kinase $(\mathrm{U} / \mathrm{L})$} & 1 & 138.83 & 132.00 & 118.67 & 7.31 & NS & 24.43 \\
\hline & 63 & 141.00 & 132.67 & 112.33 & 10.58 & NS & 35.71 \\
\hline
\end{tabular}

NS - Non-significant, SEM- Standard error mean, CD- Critical difference, CV- Coefficient of variance

catabolism of body tissue protein [15]. In the present study, supplementation of both synthetic MethionineLysine and CSC significantly decreased urea N concentration in plasma with the control. The decrease in urea nitrogen concentration indicates that supplementation of protected Methionine and Lysine to the control diet in the present study may have improved AA balance in MP and resulted in less deamination of absorbed AA. This consideration was further supported by the fact that in the present study, treatment $\mathrm{M}-\mathrm{L}$ had higher nitrogen utilization efficiency than the control group. von Keyserlingk et al. [17] observed that multiparous cows receiving the diet supplemented with bypass Methionine and bypass protein had significantly lower BUN levels when compared with the control cows and these results indicate that the formulating lower $\mathrm{CP}$ diets since cows receiving the bypass Methionine and bypass protein were able to maintain milk production.

Non-significant different values of creatine kinase were observed decrease with the effect of treatment than control. The plasma concentration of creatine kinase tended to decline with increasing blood protein meal level, it did, however, increase with age, reflecting the increasing muscle mass of the animals [16].

\section{Conclusion}

Bypass Methionine and Lysine have no effect on hematological and biochemical parameters except blood urea nitrogen (BUN) in growing Jaffrabadi heifers. This in-vivo study on Jaffrabadi heifers demonstrated the potential for supplementing Methionine and Lysine without much economic impact for improvement in digestibility of nutrients, intake of DCP and positive nitrogen balance without any effect on the health of heifers.

\section{Author's contribution}

All authors contributed equally. All authors read and approved the final manuscript.

\section{Acknowledgments}

The authors thank Kemin Industries South Asia Pvt Ltd for their generous support and providing experimental material. We would also like to thank Research Scientist, Cattle Breeding Farm and Principal, Veterinary College, JAU, Junagadh, to provide all support and facilities to conduct this experiment.

\section{Competing interests}

Authors declare that they have no competing interest.

\section{References}

1. Cheeke, P.R. (2005) Applied Animal Nutrition: Feeds and Feeding. $3^{\text {rd }}$ ed., Pearson Education Inc., Upper Saddle River, New Jersey. Pp-420-440.

2. Barman, K. and Rai, S.N. (2003) Comparative Evaluation of Cotton Seed Cake and Leucaena Leaf Meal on Profiles of Amino Acids, tannins and their Influence on Digestion Kinetics. Indian J Anim Nutri 20(4):378- 388.

3. Merchen, N.R. and Titgemeyer, E.C. (1992) Manipulation 
of amino acid supply to the growing ruminant. J Anim Sci 70(10):3238-3247.

4. Lapierre, H., Bernier, J.F., Dubreuil, P., Reynolds, C.K., Farmer, C., Ouellet, D.R. and Lobley, G.E. (2000) The effect of feed intake level on splanchnic metabolism in growing beef steers. JAnim Sci 78: 1084-99.

5. Archibeque, S.L., Burns, J.C. and Huntington, G.B. (2002) Nitrogen metabolism of beef steers fed endophytefree tall fescue hay: Effects of ruminally protected Methionine supplementation. JAnim Sci 80: 1344-51.

6. Klemesrud, M.J., Klopfenstein, T.J. and Lewis, A.J. (2000) Metabolizable Methionine and Lysine requirements of growing cattle. JAnim Sci 78(1): 199-206.

7. Liker, B., Bacar-Huskic Lina, Knezevic, M., Rupic, V., Vranesic, N. et al., (2005) Blood metabolites and haematological indices of pregnant beef cows fed rumenprotected Methionine. JAnim Feed Sci 14: 625-38.

8. Snedecor, G. W. and Cochran, W. G. (1994) Statistical Methods. $8^{\text {th }}$ ed. Affiliated East-West press Pvt. Ltd., New Delhi.

9. Liker, B., Vranesic, N., Grbesa, D., Bacar-Huskic, L. et al., (2006) Blood metabolites and hematological indices of beef cattle fed rumen-protected Methionine. Acta Veterinaria (Beograd) 56(1): 3-15.

10. Shahidullah, M., Uddin, M. and Habib, M.A.(2008) Growth and Hematological changes of commercial birds fed on blood meal supplement with water. J. Bangladesh Agril. Univ. 6(2): 321-326.

11. Donkoh, A., Atuahene, C.C., Anang, D.M. and Otori, S.K. (1999) Chemical composition of solar dried blood meal and its effect on performance of broiler chickens. Animal Feed Science and Technology 81(3-4): 299-307.

12. Odunsi, A.A., Onifade, A.A. and Babatunde, G.M. (1999) Response of broiler chicks to virginimycin and dietary protein concentrations in the humid tropics. Archivos dezootunia 48(183): 317-325.

13. Hind, A.A. Elagib, H.E. Mohamed and Elzubeir, E.A. (2008) The Effects of Methionine and Energy Levels on Hematological and Biochemical Indices in Broiler under Hot Climate. Research Journal of Poultry Sciences 2(1): 15-20.

14. Ye, J. -A., Wang, C., Wang, H. -F., Liu, H. -Y., Wang, Y. -M., Chen, B. and Liu, J. -X. (2010) Effects of pelletizing and supplementary Methionine, Lysine, and Choline on the performance of periparturient dairy cows. Acta Agriculturae Scandinavica, Section A - Animal Science 60(4): 230-238.

15. Wang, C., Liu, J.X., Zhai, S.W., Lai, J.L. and Wu, Y.M. (2008) Effect of ratio of rumen-degradable-protein to rumen-undegradable-protein on nitrogen conversion of lactating dairy cow. Acta Agric. Scand. Anim. Sci. 58: $100-103$.

16. Hellwing, A.L.F., Tauson, A. H. and Skrede, A. (2007) Blood parameters in growing pigs fed increasing levels of bacterial protein meal. Acta Veterinaria Scandinavica, 49: 33.

17. Von Keyserlingk, M. A. G., Swift, M. L. and Shelford, J. A. (1999) Use of the Cornell Net Carbohydrate and Protein System and rumen-protected methionine to maintain milk production in cows receiving reduced protein diets. Can. J. Anim. Sci. 79: 397-400.

$* * * * * * * *$ 